Jurnal Interpretasi Hukum |ISSN: 2746-5047

Vol. 2, No. 2 - Agustus 2021, Hal. 308-314| Tersedia online di

https://www.ejournal.warmadewa.ac.id/index.php/juinhum

DOI: https://doi.org/10.22225/juinhum.2.2.3432.308-314

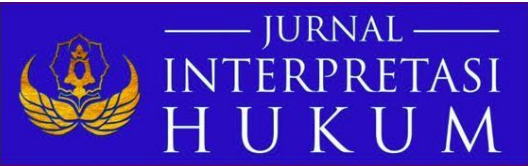

\title{
SANKSI HUKUM TERHADAP PEJABAT NEGARA YANG MELANGGAR PROTOKOL KESEHATAN DI MASA PANDEMI COVID-19
}

\author{
I Kadek Arya Andika, I Nyoman Sugiartha, I Nyoman Sutama \\ Fakultas Hukum Universitas Warmadewa, Denpasar-Bali \\ ikadekaryaandika98@qmail.com, nyomansugiartha@gmail.com, sutamainyoman62@qmail.com
}

\begin{abstract}
Abstrak
Virus corona atau yang disebut dengan Covid-19merupakan penyakit menular yang disebabkan oleh coronavirus jenis baru yang ditemukan pada akhir tahun 2019 di Kota Wuhan, China yang telah menyebar ke seluruh dunia, sudah memakan korban hingga ratusan orang meninggal dan puluhan ribu lainnya terinfeksi. Jika sebelumnya Indonesia menjadi salah satu negara yang belum terinfeksi, dan akhirnya pada bulan februari virus corona masuk ke Indonesia. Menjalarnya virus corona menyebabkan kepanikan di kalangan masyarakat Indonesia. Tujuan penelitian ini untuk mengungkap sanksi hukum terhadap pejabat negara yang melanggar protokol kesehatan di masa pandemi covid-19. Metode penelitian yang digunakan adalah metode penelitian hukum normatif yang mana perujukannya berdasarkan pada pendekatan konseptual hingga perundangundangan. Sumber bahan dan hukum yang digunakan berupa primer dan sekunder. Teknik pengumpulan data yang digunakan ialah dengan mengumpulkan referensi yang berhubungan dengan penelitian. Selanjutnya data tersebut akan diolah dan dianalisis dengan menggunakan metode pengolahan data hukum secara sistematis. Hasil penelitian ini menunjukan bahwa kasus penyebaran dan angka kematian yang disebabkan oleh virus corona kini terus bertambah cukup cepat, sejumlah negara bahkan sudah melakukan tindakan dengan cara melarang setiap warga negaranya untuk bepergian keluar negeri maupun menerima kunjungan dari warga negara asing (lockdown). Dalam rangka menangani keresahan yang dialami masyarakat Indonesia ini dan upaya untuk melakukan pencegahan penularan virus corana yang semakin hari semakin melonjak jumlah pasien yang positif, maka pemerintah mengeluarkan beberapa peraturan atau kebijakan, yaitu Peraturan Pemerintah Republik Indonesia Nomor 21 Tahun 2020, tentang Pembatasan Sosial Berskala Besar (PSBB) Dalam Rangka Percepatan Penanganan Coronavirus Disease 2019 (covid-19).
\end{abstract}

Kata kunci: Pejabat Negara, Protokol Kesehatan, Sanksi Hukum

\begin{abstract}
The corona virus or what is known as Covid-19 is an infectious disease caused by a new type of coronavirus that was discovered at the end of 2019 in the city of Wuhan, China, which has spread throughout the world, has killed hundreds of people and infected tens of thousands of others. Previously, Indonesia was one of the countries that had not been infected, and finally in February the corona virus entered Indonesia. The spread of the corona virus causes panic among Indonesian people. The purpose of this study is to uncover legal sanctions against state officials who violate health protocols during the COVID-19 pandemic. The research method used is a normative legal research method where the reference is based on a conceptual approach to legislation. Sources of materials and laws used are primary and secondary. The data collection technique used is to collect references related to research. Furthermore, the data will be processed and analyzed using legal data processing methods systematically. The results of this study indicate that cases of spread and death rates caused by the corona virus are now increasing quite rapidly, a number of countries have even taken action by prohibiting every citizen from traveling abroad or receiving visits from foreign nationals (lockdown). In order to deal with the unrest experienced by the Indonesian people and efforts to prevent the transmission of the corona virus which is increasingly increasing the number of positive patients, the government issued several regulations or policies, namely Government Regulation of the Republic of Indonesia Number 21 of 2020 , concerning Large-Scale Social Restrictions. (PSBB) in the context of accelerating the handling of the 2019 coronavirus disease (covid-19).
\end{abstract}

Keywords: State Officials, Health Protocol, Legal Sanctions

\section{PENDAHULUAN}

Semakin merebaknya virus yang dinamakan Virus corona atau COVID-19 yang mana sebagai salah satu penyakit menular dan dikatakan pandemi saat ini di seluruh dunia, yang pertama kali merebak di tahun 2019 tepatnya pada akhir tahun tersebut di Kota Wuhan, China hingga saat ini telah banyak 
memakan dan menjangkiti korbannya di dunia tak terkecuali. Saat ini di Indonesia sendiri korban terus bertambah karena keberadaan virus yang tak kunjung reda, walau sudah terdapat vaksinnya. Tepat akhir Februari 2019, virus ini masuk ke Indonesia. Keberadaan virus ini menimbulkan kepanikan di kalangan masyarakat Indonesia. Kasus penyebaran dan angka kematian yang disebabkan oleh virus corona kini terus bertambah cukup cepat, sejumlah negara bahkan sudah melakukan tindakan dengan cara melarang setiap warga negaranya untuk bepergian keluar negeri maupun menerima kunjungan dari warga negara asing (lockdown).

Salah satu upaya dengan ditetapkannya pembatasan sosial atau jaga jarak hingga karantina mandiri di rumah masing-masing, untuk menekan meningkatnya jumlah korban terjangkit. Bahkan penutupan fasilitas umum, sekolah, kantor, tempat wisata, dan aktivitas lainnya khususnya yang melibatkan banyak massa juga terpaksa harus ditutup. Dengan dikeluarkannya peraturan terkait pembatasan sosial berskala besar, tentunya masyarakat yang biasanya beraktivitas di luar rumah harus menjalankan rutinitas baru dengan prokes dan WFH atau bekerja dari rumah.

Penanggulangan dalam rangka pengurangan terhadap penyebaran virus corona ini tentunya memberikan dampak yang cukup besar bagi beberapa aspek khususnya lingkungan, mulai dari lingkungan sosial, ekonomi, religi, dan lingkungan sosial. Dengan diterapkannya pembatasan fisik (physical distancing), yang mengharuskan seseorang menjaga jarak dengan orang lainnya apabila berada di tempat umum minimal jarak 1-2 meter. Kebijakan ini dilakukan untuk menghentikan atau memperlambat penyebaran virus corona, dari hal tersebut dapat dipahami bahwa setiap orang wajib memperhatikan dan mematuhi protokol kesehatan, tidak terkecuali pejabat negara.

Beberapa kegiatan yang dilaksanakan oleh pemerintah baik pusat maupun daerah, senantiasa melibatkan masyarakat banyak, serta tidak jarang juga mengabaikan protokol kesehatan yang telah ditetapkan oleh Pemerintah. Selain banyaknya masyarakat yang melanggar atau mengabaikan protokol kesehatan, pejabat negara atau pemerintah daerah nampaknya melakukan pelanggaran protokol kesehatan yang telah ditetapkan oleh pemerintah pusat melalui kementerian kesehatan dan gugus tugas penanggulangan covid-19, yakni pada saat acara persembahyangan yang dilakukan oleh pejabat negara bersama jajarannya, pada acara tersebut terlihat pada foto yang dibagikan pada akun resmi sosial media dimana pejabat negara bersama dengan jajarannya tidak mematuhi protokol kesehatan yang ditetapkan oleh pemerintah pusat seperti wajib menggunakan masker dan menjaga jarak atau social distancing.

Dari peristiwa itu terjadinya polemik dikalangan masyarakat, kenapa jika masyarakat yang melanggar protokol kesehatan begitu cepat ditindak, baik dikenakan denda maupun sanksi hukum. Salah satu Kasus dari wakil ketua DPRD Tegal yang sedang ramai karena melakukan pelanggaran protokol kesehatan. Singkatnya terjadi saat ada kegiatan yang melibatkan banyak massa, yang tidak mengindahkan dengan protokol kesehatan yang seharusnya menjadi prioritas saat ini. Disini, sanksi hukum yang ia peroleh karena perbuatannya itu terancam dengan pasal 93 Undang-u ndang Nomor 6 Tahun 2018 tentang Kekarantinaan Kesehatan jo Pasal 216 ayat (1) KUHPidana jo Pasal 63 ayat (1) KUHPidana. Selain itu, kurangnya konsistensi dalam penerapan sanksi hukum terkait pelanggaran yang terjadi juga menjadi masalah. Sebut saja sistem penegakkan yang masih saja lemah jika menyangkut para pejabat yang berkewenangan tinggi misalnya yang seakan masih kebal hukum. Selain pengaturan kepastian hukum yang kurang, kesadaran pun masih kurang terlihat disini bagi seluruh komponen masyarakat, tak terkecuali para pejabat yang memiliki kedudukan tinggi.

Beberapa penelitian sebelumnya dengan objek yang serupa misalnya, Thorik (2020:118) yang mengkaji terkait Efektivitas kebijakan PSBB di Indonesia. Ia menilai bahwa PSBB adalah tindakan yang tepat dalam mengurangi kecepatan penyebaran wabah. Kesimpulan berbeda didapat dari penelitian yang dilakukan oleh Yunud dan Rezki dalam penelitiannya yang berjudul Kebijakan Pemerintah Lockdown Sebagai Antisipasi Penyebaran Corona Virus Covid-19menemukan bahwa kebijakan PSBB tidak efektif dalam menekan penyebaran wabah (Yunud dan Rezki, 2020:228).

Tugas pemerintah mengajak masyarakat untuk melakukan perubahan perilaku masyarakat di masa pandemi COVID-19secara integratif dan sistematis, serta terus memantau perkembangan penerapan protokol kesehatan di lingkungan masyarakat dari berbagai kalangan dan tempat selain itu perlu Satgas Percepatan Penanganan COVID-19, TNI, Polri, Satpol PP, hingga relawan untuk dapat menjadi contoh yang baik bagi masyarakat dalam menerapkan protokol kesehatan. Sementara dalam memberikan sanksi terhadap pelanggaran protokol kesehatan harus mempertimbangkan kondisi psikologis dan sosiologis bagi pelanggar. Agar masyarakat dapat memahami pentingnya menjaga 
kesehatan dengan mengimplementasikan protokol kesehatan 3M secara bersamaan dalam beraktivitas dan melakukan kegiatan sehari-hari, bukan hanya sekedar takut kepada pemberian sanksi semata dan perlu diketahui agar masyarakat lebih meningkatkan perhatian terhadap bahaya yang mengancam dari Covid-19, baik bagi diri sendiri maupun dari dan bagi orang-orang di sekitar. Sehingga penting untuk mengimplementasi 3M secara bersamaan dan disiplin (I Gede \& Surya Kharisma, 2021). Penerapan pemberian sanksi kepada pelanggar yang tidak memakai masker dan tidak melakukan physical distancing sudah sesuai dengan kebijakan yang berlaku, dan penerapan sanksi pada pelanggar protokol kesehatan tidak memiliki unsur berlebihan yang merugikan pada pelanggar. Serta memiliki nilai efektif karena menghasilkan efek jera para pelanggar agar tidak mengulangi perbuatannya lagi (Erwin Dwijaryantak, 2021). Untuk mencegah penyebaran yang semakin luas, maka pemerintah Indonesia melakukan banyak perubahan tatanan bernegara, yang diikuti oleh pemerintah daerah setempat. Hal ini menindaklanjuti Intruksi Presiden Nomor 6 Tahun 2020 tentang Peningkatan Disiplin dan Penegakan Hukum Protokol Kesehatan dalam Pencegahan dan Pengendalian Corona Virus Disease 2020 (Ida Bagus \& Ngurah Oka, 2020)

Berdasarkan paparan penjelasan diatas, maka dirumuskan tujuan dari penelitian yakni untuk mengetahui sanksi hukum terhadap pejabat negara yang melanggar protokol kesehatan di masa pandemi covid-19.

\section{METODE PENELITIAN}

Dalam penyusunan setiap penelitian ini digunakan metode normatif, yang mana perujukannya berdasarkan pada pendekatan konseptual hingga perundang-undangan. Ada beberapa bahan hukum primer yang mana diperoleh dari Undang-undang Nomor 6 Tahun 2018 tentang Kekarantinaan Kesehatan, Undang-undang Nomor 4 tahun 1984 tentang Wabah Penyakit Menular, Undang-undang Nomor 36 Tahun 2009 tentang Kesehatan hingga Peraturan Pemerintah Republik Indonesia Nomor 21 Tahun 2020. Selain itu penggunaan bahan hukum sekunder lainnya seperti buku-buku literatur, jurnaljurnal terkait juga membantu penelitian ini (Beny Ahmad, 2008 13). Jenis pendekatan yang dilakukan dengan menelaah dari semua peraturan perundang-undangan yang berkaitan dengan isu hukum yang sedang dihadapi sedangkan pendekatan konseptuan adalah pendekatan yang beranjak dari doktrin dan perundang-undangan yang berkembang diilmu hukum guna memperjelas ide-ide dengan membeikan pengertian hukum, konsep hukum, maupun asas hukum. Teknik pengumpulan data dilakukan dengan mengumpulkan referensi dari beberapa jurnal, buku, atau literature yang berkaitan dengan objek penelitian. Selanjutnya data dianalisis menggunakan metode pengolahan data hukum secara sistematis.

\section{HASIL DAN PEMBAHASAN}

\section{Pengaturan Hukum Terhadap Pejabat Negara Dalam Mematuhi Protokol Kesehatan}

Sri Soemantri berpendapat dalam bukunya bahwa lembaga Negara tidak hanya terbatas pada apa yang diatur dalam konstitusi. Mengingat pada pendapatnya, terdapat 2 sistem ketatanegaraan di Indonesia, yaitu dalam arti sempit dan arti luas. Dimana jika hanya memandang lembaga Negara yang ada dalam Undang-Undang Dasar, itu merupakan sistem ketatanegaraan dalam arti sempit, sedangkan sebaliknya disebut sebagai sistem ketatanegaraan dalam arti luas (Sri Soemantri Martosoewignjo, 1981).

Didefinisikannya hukum sebagai suatu himpunan peraturan yang berisikan petunjuk hidup berupa perintah dan larangan disebut oleh E.Utterecht yang mana menjabarkan tujuannya dalam mengatur tata laksana dalam masyarakat yang mana para pejabat juga masuk didalamnya. Menurut Kamus Besar Bahasa Indonesia (KBBI), hukum merupakan adat atau peraturan yang sifatnya mengikat karena keresmiannya, dan penguasa atau pejabatlah yang berwenang untuk mengukuhkannya. Salah satu bentuknya adalah Undang-undang yang dijadikan pedoman aturan untuk melakukan pengaturan dalam kehidupan bermasyarakat. Dan apabila tidak dijalankan sebagaimana diatur di dalamnya, maka pengenaan sanksi merupakan konsekuensi yang dijadikan dasar penjatuhan hukuman terhadap mereka.

Dalam menjaga esensi dari hukum diperlukan kekuatan dapat berupa dari organisasi yang dapat digunakan oleh hukum untuk bersandar, sehingga nilai dan kekuatannya dapat dijaga untuk dapat dijadikan sistem untuk menjalin kepentingan masyarakat umum. Maka untuk itu diperlukan organ dari suatu komunitas contohnya untuk melakukan penjagaan terhadap hukum yang ada kelegalan suatu norma dapat diperoleh apabila norma tersebut melekat sanksi di dalamya, tak 
terkecuali jika norma harus berhubungan dengan yang lainnya atau tidak dapat berdiri sendiri. (Antonius Cahyadi dan E \& Fernando M. Manullang, 2007).

Penerapan aturan terkait adanya aturan yang tak diindahkan oleh setiap orang dalam prakteknya, yang mana dilakukan baik sengaja ataupun tidak bahkan bagi mereka yang berkewenangan tinggi sekalipun tak dapat dikecualikan, hal ini sedefinisi dengan persamaan setiap orang di mata hukum. Hal tersebut dapat ditemukan perumusannya pada Peraturan terkait yaitu dalam Pasal 14 ayat (1) atau (2) Undang Undang Nomor 4 Tahun 1984.

Melalui Keppres Nomor 11 Tahun 2020 hingga kebijakan terkait pembatasan kegiatan masyarakat dilakukan sebagai upaya pemerintah untuk membuat kebijakan baru untuk melakukan pengaturan yang relevan sifatnya dengan kondisi saat ini terkait keadaan yang disebut Kedaruratan Kesehatan sehingga dapat dilakukan upaya untuk mencegah semakin meluasnya bahaya wabah yang terjadi dengan penerapan protokol kesehatan yang diatur di dalamnya. Imbauan protokol kesehatan (prokes) yang saat ini sering terdengar di telinga kita adalah pelaksanaan 3M, sebut saja melakukan cuci tangan, menjaga jarak dan memakai masker. Inilah kunci penting dalam penerapan protocol kesehatan yang dimaksud terkait kondisi Covid-19yang terjadi saat ini.

Mengingat berbagai kebijakan baru yang terbit sebagai dampak dari terjadinya kondisi Penyebaran Covid-19saat ini menimbulkan sanksi juga yang nantinya akan dikenakan bagi para pelanggar. Sebut saja kebijakan terkait pembatasan kegiatan masyarakat hingga penerapan protocol kesehatan misalnya, jika dilakukan pelanggaran maka akan menimbulkan akibat hukum berupa penjatuhan sanksi yang sesuai. Hal ini berkaitan dengan Kebijakan publik yang mana menurut Thomas R. Dye sebagai suatu hal yang diterapkan untuk dilakukan oleh pemerintah untuk dilakukan atau tidaknya suatu hal tertentu. Jadi setiap tindakan yang dilakukan pemerintah termasuk dalam suatu kebijakan publik yang peruntukannya bagi publik tentunya sehingga tujuannya pun harus jelas juga (Pasolong Harbani, 2011).

Kebijakan publik ada yang sifatnya memaksa terhadap tindakan privat suatu masyarakat luas, ada pula ciri pokok lainnya yaitu tentu dalam pembuatan dan pemrosesannya menjadi kewenangan suatu lembaga pemerintahan sesuai prosedur yang ditetapkan juga. Untuk itu sifat memaksa dan mengikat ini timbul karena tertuang dalam ketentuan aturan hukum yang ada.

Dari hal tersebut, kebijakan yang dibuat oleh pemerintah juga merupakan hukum yang dibuat untuk ditaati dengan tujuan mencapai tujuan hukum itu sendiri dan kepentingan masyarakat. Dari sini, setiap kebijakan dalam masa Covid-19saat ini merupakan hukum yang berlaku bagi masyarakat tak terkecuali para pejabat. Namun dalam perjalanan prakteknya, tak sedikit, contoh buruk malah diperlihatkan para pejabat kepada masyarakat umum dalam menghadapi kebijakan yang ada dalam kondisi saat ini.

Sebut saja di Provinsi banten misalnya, terjadi pelanggaran prokes oleh oleh pejabat negara. Tidak mengindahkan social distancing atau jaga jarak dalam melakukan kegiatan yang mengerahkan banyak massa pada kondisi saat ini. Dari situ timbul berbagai reaksi dari perbuatan tersebut baik dikarenakan ketidakteraturan yang terjadi sebagai akibat kekacauan yang timbul menjadi perbincangan masyarakat. Kurangnya kesadaran hukum dalam menerapkan prokes menjadi momok dan musuh bagi kita semua, sehingga harus cepat untuk diatasi dalam situasi saat ini.

Penerapan protokol kesehatan dilakukan oleh seluruh setiap lapisan masyarakat tak terkecuali anggota Aparatur Sipil Negara (ASN). Pelanggaran prokes oleh ASN juga berarti pelanggaran terhadap kedisiplinan pegawai negeri sipil. Disiplin Pegawai Negeri Sipil merupakan kesanggupan para PNS dalam menaati setiap kewajiban hingga larangan yang diatur serta telah tertera dalam ketentuan setiap peraturan perundang-undangan dan/atau peraturan kedinasan yang ada, dan untuk itu jika tidak ditaati, pengenaan sanksi hukuman disiplin dapat dijatuhi. Berdisiplin tinggi bagi pejabat negara pada hakekatnya bermakna ketaatan pada norma-norma atau kaidah-kaidah yang diyakini sebagai panggilan luhur untuk mengemban amanah serta kepercayaan masyarakat. Disiplin tinggi akan mendorong terbentuknya pribadi yang tertib di dalam melaksanakan tugas, ikhlas dalam pengabdian, dan berusaha untuk menjadi teladan dalam lingkungannya, serta tidak menyalahgunakan amanah yang dipercayakan kepadanya.

Penjaminan kepastian hukum dengan diperkuatnya upaya dalam meningkatkan efektivitas pencegahan hingga pengendalian Coronavirus Disease 2019 di seluruh daerah provinsi serta kabupaten/kota di Indonesia, untuk itu melalui aturan seperti melalui Inpres Nomor 6 Tahun 2020, diinstruksikan kepada setiap lembaga negara untuk dapat melakukan hal yang diperlukan terkait tugas 
dan fungsi mereka masing-masing guna terjaminnya kepastian hukum dan nantinya diharapkan upaya pencegahan serta pengendalian dalam situasi saat ini dapat merata ke seluruh wilayah di Indonesia.

Sebut saja lembaga Negara terkait dalam instruksi tersebut adalah para Sekretaris Kabinet, Kepala Kepolisian Negara Republik Indonesia, Menteri Kabinet Indonesia Maju, Panglima Tentara Nasional Indonesia, , Para Kepala Lembaga Pemerintah Non Kementerian, hingga Kepala Daerah Provinsi maupun Kabupaten/Kota. Instruksi terkait untuk meningkatkan disiplin prokes ini nantinya dapat menginisiasi munculnya peraturan daerah misalnya baik di tingkat provinsi maupun Kabupaten/ Kota untuk menindaklanjuti kebijakan tersebut, sebut saja dengan melakukan penyuluhan terkait pelaksanaan prokes kepada masyarakat agar tidak abai yang mana juga dapat didukung dari pihak lain seperti aparat penegak hukum sebut saja TNI/POLRI misalnya untuk membantu dalam pengawasannya. Untuk itu sosialisasi ini harus didukung juga dengan keterlibatan berbagai berbagai elemen lapisan masyarakat seperti tokoh adat, pemuka agama, tokoh masyarakat dan lain sebagainya.

\section{Sanksi Hukum Terhadap Pejabat Negara yang Melanggar}

Semakin banyaknya korban terdampak Covid-19bahkan hingga korban meninggal dunia semakin meluas dan terus meningkat seiring waktu, hal ini memberi pengaruh terhadap kondisi baik ekonomi, politik, sosbud, ketertiban hingga kesejahteraan masyarakat. Untuk itu kondisi situasi saat ini dikatakan sebagai kedaruratan kesehatan. Hal ini tertuang dalam Keputusan Presiden Nomor 11 tahun 2020, sehingga tegas diatur di dalamnya. Kondisi ketika suatu keadaan dimana kesehatan masyarakat terancam secara luar biasa, bahkan hingga Pemerintah mendeklarasikan sebagai suatu ancaman yang besar dengan pengaruhnya ke dalam berbagai aspek kehidupan disebut sebagai kedaruratan kesehatan. Ini dilihat dari seberapa besar efek dari masalah yang sedang dihadapi, begitu juga terkait dengan jumlah hitung-hitungan dalam kondisi terburuk sekalipun. Maka dari itu, pemberlakuan karantina atau isolasi merupakan salah satu respon pemerintah akan bahaya dari kondisi yang terjadi saat ini (Arasy Pradana, 2002:33)

Terhambatnya pelaksanaan hukum itu sendiri guna mencapai ketertiban dan keteraturan di masyarakat dengan adanya pelanggaran akan apa yang tertuang dalam ketentuan perundng-undangan dapat disebut sebagai perbutaan pidana yang mana dapat merugikan masyarakat umum luas. Dari hal ini, apabila suatu perbuatan yang dilarang oleh aturan hukum dilakukan atau pelanggaran terjadi, maka Perbuatan seseorang tersebut dikatakan sebagai tindak pidana.

Virus Corona yang mudah menular dan menjangkiti korbannya cukup berbahaya termasuk dapat mengancam nyawa sebagian korbannya jika terdapat penyakit bawaan. Maka untuk itu, kesadaran dalam menerapkan protokol kesehatan dan pola hidup sehat dan bersih diperlukan, sebagaimana anjuran kebijakan yang ada pula. Karena segala hal terkait itu sebua dapat kita temukan pengaturannya dalam aturan hukum yang ada, sehingga sanksinya tak main-main pula.

Pada dasarnya, karena telah disumpah jabatan, maka setiap pejabat negara berkewajiban memegang teguh hal itu, sehingga dapat menjunjung tinggi standar yang telah ada berkaitan dengan etika hingga moral mereka. Dan menjaga reputasi serta berintegritas terhadap jabatannya wajib dilakukan pejabat Negara, sebagaimana tertuang dalam kode etik mereka masing-masing berkaitan kedisiplinan.

Presiden sebagai pemegang kekuasaan tertinggi dalam pemerintahan dalam hal membuat kebijakan hingga mengatur terkait manajemen aparatur negara. Diciptakannya peraturan terkait kebijakan yang akan diterapkan guna mencapai ketertiban dan upaya perlindungan kepada masyarakat. Selain itu melakukan penyuluhan dan pelatihan kepada aparatur Negara melalui lembaga Negara untuk menyiapkan kompetensi yang telah memiliki standarnya.

Penetapan kebijakan dari Presiden terkait pandemi covid 19, salah satunya memuat mengenai peningkatan disiplin dan penegakan hukum protokol kesehatan di seluruh wilayah Indonesia. Kebijakan tersebut diinstruksikan kepada beberapa pejabat negara, yaitu para Menteri, sekretaris Kabinet, Panglima TNI, Kapolri, Kepala Lembaga Pemerintah Non Kementerian, Para Gubernur hingga Para Bupati/Walikota. Atas hadirnya kebijakan tersebut terkait untuk meningkatkan kedisiplinan prokes khususnya, maka instruksi tersebut harus diindahkan tentunya.

Implementasi dari Instruksi Presiden mengenai peningkatan disiplin protokol kesehatan dilaksanakan dari oleh Pemerintah daerah baik ditingkat provinsi maupun kabupaten/kota. Dengan adanya peraturan di berbagai tingkat saat ini, diperlukan untuk menjembatani kebijakan dari pusat ke daerah sehingga terjadi pemerataan dan satu tujuan yang selaras dalam upaya penanganan kondisi saat ini. Melalui Peraturan Gubernur, kewenangan diberikan guna melaksanakan kuasa yang telah 
diamanatkan dari aturan diatasnya. Adapun subjek dari Peraturan Gubernur No. 46 Tahun 2020 adalah setiap orang, baik perorangan, pengelola, pelaku usaha, Penanggung Jawab Tempat dan Fasilitas Umum maupun penyelenggara suatu kegiatan misalnya. Sanksi yang dikenakan berupa administratif bagi pelanggaran perorangan dengan denda mencapai Rp. 100.000,00 (Seratus ribu rupiah) untuk pelanggaran pemakaian masker sebagaimana tertuang dalam Peraturan gubernur tersebut. Selain itu berupa penghambatan dalam pelayanan administratif juga dapat dikenakan bagi para pelanggar ketentuan dalam kebijakan ini. Sedangkan sanksi administratif berupa denda Rp. 1.000.000,00 (Satu juta rupiah) hingga pempublikasian para pelanggar berlaku bagi setiap pengelola, penyelenggara, pelaku usaha hingga penanggung jawab tempat dan fasilitas umum, yang terbukti tak mengindahkan protocol kesehatan sesuai amanat Peraturan Hukum yang berlaku salah satunya Pergub ini. Tak main-main, rekomendasi pembekuan sementara izin usaha kepada pejabat/instansi yang berwenang juga dapat dilakukan. Melalui surat bukti yang dikeluarkan Satpol PP, sanksi atau denda administratif dapat dikenakan atas dasar hal itu. Pembayaran dilakukan melalui sistem tunai atau non tunai yang disetorkan ke Kas Daerah Provinsi berdasarkan ketentuan Peraturan Perundang-undangan. Untuk sanksi terkait pempublikasian ke media massa akan menjadi tindak lanjut jika tidak mengindahkan metode pertama yaitu pembayaran denda. Batas waktunya pun diatur yaitu selama tujuh 7 hari kerja terhitung dari surat bukti diterima. Jika terjadi perlawanan dengan kekerasan, maka ancaman pidana dapat dijatuhi karena sifatnya sudah menghambat aparat berwenang dalam menjalankan tugas mereka. Itu juga berlaku bagi mereka yang dengan sengaja menghalangi, menggagalkan hingga mencegah pejabat dalam melakukan tugasnya sebagaimana diperintahkan oleh aturan perundangan yang ada, maka pengenaan sanksi pidana dapat menjadi solusinya.

Selain itu ada pula Undang-undang Kekarantinaan Kesehatan dengan ancaman pidananya, bagi mereka yang terbukti tak mematuhi dan tak bekerjasama dalam upaya pengkarantinaan kesehatan, termasuk upaya penghalangan sehingga terjadi kedaruratan kesehatan. Pemberian sanksi kepada Pejabat Negara dan Aparatur Sipil Negara dilakukan oleh Presiden selaku pemegang kekuasaan tertinggi pembinaan ASN, Terhadap keputusan yang ditetapkan oleh Pejabat Pembina Kepegawaian. Selain presiden, pemberian sanksi dapat dilakukan oleh Menteri terhadap keputusan yang ditetapkan oleh Pejabat yang Berwenang, serta terhadap Pejabat Pembina Kepegawaian di tingkat provinsi dan kabupaten/kota.

\section{SIMPULAN DAN SARAN \\ 1. Simpulan}

Dari pemaparan hasil penelitian diatas dapat disimpulkan Melalui Keppres Nomor 11 Tahun 2020 hingga kebijakan terkait pembatasan kegiatan masyarakat dilakukan sebagai upaya pemerintah untuk membuat kebijakan baru untuk melakukan pengaturan yang relevan sifatnya dengan kondisi saat ini terkait keadaan yang disebut Kedaruratan Kesehatan sehingga dapat dilakukan upaya untuk mencegah semakin meluasnya bahaya wabah yang terjadi dengan penerapan protokol kesehatan yang diatur di dalamnya. Imbauan protokol kesehatan (prokes) yang saat ini sering terdengar di telinga kita adalah pelaksanaan 3M, sebut saja melakukan cuci tangan , menjaga jarak dan memakai masker. Inilah kunci penting dalam penerapan protocol kesehatan yang dimaksud terkait kondisi Covid-19yang terjadi saat ini. Kebijakan yang dibuat oleh pemerintah juga merupakan hukum yang dibuat untuk ditaati dengan tujuan mencapai tujuan hukum itu sendiri dan kepentingan masyarakat. Dari sini, setiap kebijakan dalam masa Covid-19saat ini merupakan hukum yang berlaku bagi masyarakat tak terkecuali para pejabat. Na mun da lam perjalanan prakteknya, tak sedikit, contoh buruk malah diperlihatkan para pejabat kepada masyarakat umum dalam menghadapi kebijakan yang ada dalam kondisi saat ini. Para pelanggar kebijakan terkait kondisi saat ini dapat dikenakan sanksi baik administratif hingga pidana. Itu berlaku juga bagi pejabat negara hingga Aparatur Sipil Negara (ASN). Presiden selaku pemegang kekuasaan tertinggi berwenang untuk itu, terkait dengan pembinaan terhadap ASN.

\section{Saran}

Saran dari penelitian ini bahwa diharapkan penerapan aturan terkait adanya aturan yang tak diindahkan oleh setiap orang dalam prakteknya, yang mana dilakukan baik sengaja ataupun tidak bahkan bagi mereka yang berkewenangan tinggi sekalipun tak dapat dikecualikan, hal ini sedefinisi dengan persamaan setiap orang di mata hukum. Untuk menghindari system penegakan hukum yang hanya memberatkan kalangan masyarakat bawah, diharapkan kesadaran hukum baik bagi masyarakat 
umum hingga pejabat Negara, karena pejabat Negara sebaiknya memberikan contoh yang nyata dan baik adanya kepada masyarakat. Seperti dalam penerapan prokes misalnya.

\section{DAFTAR PUSTAKA}

Ahmad, B. (2008). Metode Penelitian. Pustaka Setia. Bandung.

Brahmana, I. B., \& Ngurah Oka Yudistira Darmadi. (2020). Penindakan Terhadap Masyarakat Yang Tidak Menggunakan Masker Sebagai Pelaksanaan Protokol Kesehatan Baru Di Provinsi Bali. Kertha Desa, Vol 8(8).

Cahyadi, A., \& M, E. F. (2007). Pengantar Ke Filsafat Hukum. Kencana Prenada Media Group, Jakarta.

Harbani, P. (2011). Teori Administrasi Publik, Bandung. Alfabeta. Bandung.

Kusuma, E. D. (2021). Physical Distancing Dan Penggunaan Masker Berdasarkan Perwali Batu Nomor 78 Tahun 2020. Dinamika: Jurnal Hukum, Vol 27(26).

Martosoewignjo, S. S. (1981). Pengantar Perbandingan Antar Hukum Tata Negara. CV Rajawali, Jakarta.

M.K,I. G., \& W.A, S. K. (2021). Sikap Tegas Pemerintah Dalam Upaya Memberikan Sanksi Pada Pelanggar Protokol Kesehatan Covid-19. Ganesha Civic Education, Vol. 3(1).

Pradana, A. (2002). Hukum Kesehatan-Penanganan SARS di Indonesia. Sinar Grafika. Jakarta.

Thorik, S. H. (2020). Efektivitas pembatasan sosial berskala besar di Indonesia dalam penanggulangan Pandemi Covid-19. Hukum Dan Keadilan, Vol 4(1).

Yunus, N. R., \& Rezki, A. (2020). Kebijakan Pemerintah Lockdown Sebagai Antisipasi Penyebaran Corona Virus Covid-19. Sosial \& Budaya Syari, Vol 7(3). 